\title{
Rationalizing the impact of aging on fiber-matrix interface and stability of cement-based composites submitted to carbonation at early ages
}

\author{
G. H. D. Tonoli ${ }^{1, \star}$, V. D. Pizzol ${ }^{1}$, G. Urrea², S. F. Santos ${ }^{3}$, L. M. Mendes ${ }^{1}$, V. Santos ${ }^{2}$, V. M. John ${ }^{4}$, M. Frías ${ }^{5}$, \\ and H. Savastano Jr. ${ }^{2}$ \\ ${ }^{1}$ Department of Forest Science, Universidade Federal de Lavras (UFLA), C.P. 3037, Lavras, MG 37200-000, Brazil \\ ${ }^{2}$ Department of Biosystems Engineering, Faculdade de Zootecnia e Engenharia de Alimentos, Universidade de São Paulo (USP), \\ Avenida Duque de Caxias Norte, 225, Pirassununga, SP 13635-900, Brazil \\ ${ }^{3}$ Department of Materials and Technology, Faculdade de Engenharia, Universidade Estadual Paulista (UNESP), v. Ariberto Pereira \\ da Cunha, 333, Guaratinguetá, SP 12516-410, Brazil \\ ${ }^{4}$ Department of Construction Engineering, Escola Politécnica, Universidade de São Paulo, São Paulo, SP 05508-900, Brazil \\ ${ }^{5}$ Eduardo Torroja Institute for Construction Science (CSIC), C/Serrano Galvache, 4, 28033 Madrid, Spain
}

Received: 23 February 2016

Accepted: 10 May 2016

Published online:

31 May 2016

(C) Springer Science+Business

Media New York 2016

\begin{abstract}
The objective of this work is to show the effect of carbonation at early stages on fiber-cement composites and impact on hydration, chemical and dimension stability. Carbonation increased the content of $\mathrm{CaCO}_{3}$ polymorphs and consumed $\mathrm{Ca}(\mathrm{OH})_{2}$ and other hydrated calcium phases. Micrographs and energydispersive spectrometry showed the $\mathrm{CaCO}_{3}$ formed is precipitated in the pore structure of the matrix, decreasing diffusion of $\mathrm{Si}, \mathrm{S}$, and $\mathrm{Al}$ during hydration. Therefore, a refining process of pore sizes is produced, and fiber-matrix interface in carbonated composites was improved, leading to volume stabilization of the composite, as indicated by lower drying shrinkage and lower porosity.
\end{abstract}

\section{Introduction}

Fiber-cement materials have been widely used in the civil engineering worldwide due to their versatility for manufacturing construction elements, such as flat boards for walls, sidings, corrugated sheets, and tubes, present in most of houses in developing regions as well as in agricultural and industrial buildings [1-3]. The major disadvantage in the use of cellulose fibers as alternative reinforcing in cement- based composites is their mineralization in the high alkalinity of the Portland cement matrix, which also led to degradation of their constituents. The mineralization of the cellulose fibers causes fiber embrittlement. Furthermore, the shrinkage of the cellulose fibers during mineralization prejudices the quality of the fiber bridging [4-9] and then decreases the composite ductility during its lifetime.

Durability of pre-cast concrete is improved with early age carbonation [10-13] because relatively

Address correspondence to E-mail: gustavotonoli@yahoo.com.br 
insoluble crystalline calcium carbonate $\left(\mathrm{CaCO}_{3}\right)$ polymorphs are formed mainly not only from the soluble $\mathrm{Ca}(\mathrm{OH})_{2}$, but also from other hydrated phases of cement such as $\mathrm{C}-\mathrm{S}-\mathrm{H}$ gel, ettringite, and carboaluminates [14]. The $\mathrm{CaCO}_{3}$ polymorphs are vaterite (Va) and calcite when precipitated at low temperatures $\left(14-30^{\circ} \mathrm{C}\right.$ ), and aragonite (Ar) and calcite at high temperatures $\left(60-80{ }^{\circ} \mathrm{C}\right)[15,16]$. Va and $\mathrm{Ar}$ are metastable calcium carbonate phases that take several hours (for $\mathrm{Va}$ ) and months (for Ar) to be transformed in calcite at room temperature [16-18]. Furthermore, Tzotzi et al. [19] suggest that temperature and $\mathrm{pH}$ are important factors controlling the formation of the final crystalline phase, although calcite is thermodynamically the most stable $\mathrm{CaCO}_{3}$ polymorph under ambient conditions.

The accelerated carbonation of the cement matrix can be applied to improve the durability of the cellulose fiber-cement composites, because it reduces the alkalinity of the cement matrix, lowering the $\mathrm{pH}$ for values lower than 9, and making this environment less aggressive to the cellulose fibers [20, 21]. According to Soroushian et al. [13], $\mathrm{CO}_{2}$ curing of cellulose fiber-cement has shown to enhance engineering properties, including dimensional stability of the final product. Furthermore, the consequences of carbonation are the stability of the mechanical behavior [13], densification of the cementitious matrix and reduction of its permeability (capillary) and porosity, which constitutes a positive process with respect to the pores sealing of the cementitious material [22]. In a previous study, Tonoli et al. [23] showed the necessity to anticipate the fast carbonation for initial periods of cure, which would not allow time for the alkali to attack the cellulose fibers during the cement hydration. The morphology and distribution of the hydration products formed during the carbonation curing, hardening, and secondary hydration of cement (dominated by AFm, AFt, and other minority phase)-based composites cannot yet be controlled with the same precision as for metals and other engineered materials, but the better understanding may permit new strategies for predicting the evolution of microstructure and properties, and ultimately engineering microstructure and overall performance. Additionally, there is still a lack of information about the changes promoted by the carbonation at early ages and after the exposition to accelerated aging cycles on the mineralogical phase composition at the transition zone of cellulose fibers and microstructure of the fiber-cement composites [24]. The objective of this work was to analyze the evolution of the fiber to matrix interface and chemical and dimension stability promoted by the use of carbonation at early ages and after accelerated aging of fiber-cement composites.

\section{Materials and methods}

\section{Sampling and carbonation at early age}

The composites with nominal thickness of $4 \mathrm{~mm}$ were obtained from the Hatschek process, which is worldwide the most employed in the fiber-cement industry. This process consists of manufacturing and stacking thin laminas (around $1 \mathrm{~mm}$ ) of fiber-cement from aqueous slurries of cement, additives, and fibers (cellulose pulp and/or synthetic). The slurry is transported to the vats with sieve cylinders where the wet solid mat is deposited, transferred to a running felt, and vacuum-drained before cutting, shaping, and curing. Detailed description of the Hatschek process was presented in Dias et al. [25].

The formulation used in the current work is composed of around $70 \%$ of Brazilian ordinary Portland cement [26], with granulated blast furnace slag (based on ASTM C150/C150 M - 12, Type IV, 2012), $24 \%$ of calcium carbonate filler, and around $6 \%$ of eucalyptus-bleached cellulose pulp and polyvinyl alcohol (PVA) fibers.

Preconditioned (in water-saturated air for $1 \mathrm{~h}$ ) samples were submitted to $10 \mathrm{~h}$ of accelerated carbonation in a climate chamber as performed in Pizzol et al. [27]. Then, the carbonated composites were taken out and preserved in water-saturated air at around $25{ }^{\circ} \mathrm{C}$ until the characterization tests. Noncarbonated specimens were maintained in the same conditions, however, without applying $\mathrm{CO}_{2}$. The fiber-cement samples were cut into test specimens $(160 \mathrm{~mm} \times 30 \mathrm{~mm} \times 4 \mathrm{~mm})$ with a diamond disk cooled with water.

\section{Soak and dry accelerated aging cycles}

Composites were successively immersed into water at $20 \pm 5^{\circ} \mathrm{C}$ for $170 \mathrm{~min}$ and, after $10 \mathrm{~min}$ of interval, they were heated to $70 \pm 5{ }^{\circ} \mathrm{C}$ for $170 \mathrm{~min}$ in an oven. Another interval of $10 \mathrm{~min}$ (at room temperature) is 
usual prior to the beginning of the next cycle, as recommended by EN 494 [28] standard. Each soak and dry set represents one cycle, which was repeated 200 times, as used in Tonoli et al. [29]. The soak and dry accelerated aging cycles contemplate comparative analysis of the microstructure and properties of the composites, before and after this test, in order to simulate natural aging in severe conditions.

\section{Scanning electron microscopy}

A back-scattered electron (BSE) image detector working at around 15.0 and $20.0 \mathrm{kV}$ was applied for viewing cut and polished surfaces. The BSE imaging was used to study the transition zone of the cellulose fibers. The preparation of specimens for BSE was accomplished with vacuum (80 kPa gage) impregnation using epoxy resin. BSE samples were manually polished with silicon carbide abrasive paper with sequential grit sizes of 320,600, 1200, and 2000 for 2 min each, using alcohol as lubricant. A polishing was carried out using in turn $8-4,4-2$, and $1-0 \mu \mathrm{m}$ diamond polishing compound during 4, 2, and $1 \mathrm{~min}$ each size, respectively. Polished samples were carbon coated before being analyzed in a FEI Quanta 600 (FEG) microscope. Energy-dispersive spectrometry (EDS) mapping analysis was performed in order to localize the carbon $(\mathrm{C})$, calcium $(\mathrm{Ca})$, silicon $(\mathrm{Si})$, and sulfur (S) atoms around the cellulose fibers on the polished surface of cross-section of the specimens. Around twenty SEM micrographs were obtained for each composite treatment and the more representative images of the microstructure were used for characterization of the microstructure.

Textural study of the fractured surface of the samples was performed using secondary electrons (SE) detector on a Hitachi S-4800 with tungsten source and detector Bruker X-Flasb 5030. SEM micrographs were obtained for each composite treatment and just the typical images of the observed microstructure were used in this manuscript.

\section{X-ray diffraction (XRD)}

Diffractometer Bruker D8 Advance model consisted of a high-voltage generator $3 \mathrm{~kW}$ X-ray tube with copper anode $(\mathrm{CuK} \alpha$ radiation of $1.54 \AA$ ), usually operating at $40 \mathrm{kV}$ and $50 \mathrm{~mA}$, lynxeye detector, carrying an anti-scatter slit of $3 \mathrm{~mm}$ and a filter of $\mathrm{Ni}$ K-beta $(0.5 \%)$. The data were collected from $5^{\circ}$ to $70^{\circ}$
(20) for $2 \mathrm{~h}$, rotating the samples at $15 \mathrm{rpm}$ to enhance particle statistics.

\section{Thermogravimetric analysis (TGA)}

To check the carbonation extension, thermogravimetric (TGA) analysis was recorded with a Netzsch equipment with STA 409 simultaneous analysis system using a dynamic nitrogen stream (flow rate $=100 \mathrm{~cm}^{3} / \mathrm{min}$ ) at a heating rate of $10^{\circ} \mathrm{C} / \mathrm{min}$. It was used the same mass (around $30 \mathrm{mg}$ ) for all samples, in order to reduce inaccurate results from heterogeneous mass quantity [30, 31]. Two sub-samples were used per treatment.

\section{Drying shrinkage and physical properties}

Apparent void volume (AVV), water absorption (WA), and bulk density (BD) of the composites were calculated from the average of six test specimens $(160 \mathrm{~mm} \times 30 \mathrm{~mm} \times 4 \mathrm{~mm})$ for each condition, following the procedures specified by ASTM C 948-81 [32].

Drying shrinkage was measured following the recommendations of standard procedures [33]. After the 10 days of curing (preserved in a water-saturated air), the specimens were cut (with $160 \mathrm{~mm} \times$ $30 \mathrm{~mm} \times 4 \mathrm{~mm}$ nominal dimension), measured about their initial length (before drying) and placed at $23 \pm 5{ }^{\circ} \mathrm{C}$ and $50 \%$ relative humidity. The length variation $(\mathrm{mm} / \mathrm{m})$ of the composites during 16 days of drying shrinkage was determined in relation to the initial condition (water vapor saturated). The values of length reduction during the drying operation were divided by the initial length of the specimens in order to find the length variation in $\mathrm{mm} / \mathrm{m}$.

\section{Results and discussion}

\section{Changes in the morphology of the fiber to matrix interface (transition zone)}

In the fiber-cement composites, especially those produced by the Hatschek process, the carbonation of the matrix is enhanced due to its high initial porosity in consequence of significant volume of fibers and also due to the applied vacuum drainage in the fabrication process, which facilitates the penetration of $\mathrm{CO}_{2}$ within the composite. Figure 1 depicts the SEM 
images in back-scattered electron (BSE) mode for the observation of the morphological features of cut and polished surfaces of control (non-carbonated) and early age carbonated composites both after 200 accelerated aging cycles. The SEM micrographs shown are typical images of the microstructure chosen from around 10 representative images for each composite treatment.

SEM/BSE permits the easy identification of cementitious phases since electron scattering goes with the atomic number. Dark areas in the image (due to low atomic number) pertain to cross-section of the fibers and black to voids. Cracks and a more porous matrix are observed surrounding the cellulose fibers in the control (non-carbonated) composite (arrows in Fig. 1a, b). This is the indicative of a weak contact between cellulose fibers and matrix in the non-carbonated composites. The cement matrix of the carbonated composite (including around the fibers) is denser and compact (Fig. 1c, d), improving the contact between fibers (both cellulosic and synthetic) and cement matrix, and possibly favoring the better adhesion between them. The cellulose fiber debonding from the matrix must be the result of its great shrinkage. Consequently, the increased porosity of the matrix near the interface at the initial ages of hydration may prejudice the fiber-cement performance [34]. Early carbonation contributes to decrease these voids around the cellulose fibers. Farahi et al. $[35,36]$ also observed very little porosity at the interface between aggregate particles and groundmass when composites were submitted to supercritical carbonation. Santos et al. [25] observed changes in the nanostructure in the vicinity of the fiber by energy-dispersive $X$-ray spectroscopy maps in extruded cement-based composite after early supercritical carbonation and before accelerated aging. However, the early carbonation did not prevent the re-precipitation of hydration products inside the cellulose fibers, as shown by arrows in Fig. 1c, d. Individual cellulose fibers present an internal cylindrical/elliptical cavity called lumen, where cement hydration products can re-precipitate when conditions are favorable. For control composites, almost none fiber lumen is filled with hydration/carbonation products (Fig. 1a, b), probably because there is no fast curing of those ions into the fibers, and they probably continue moving into the microstructure. In the carbonated composites, the hydration products became entrapped into the microstructure when
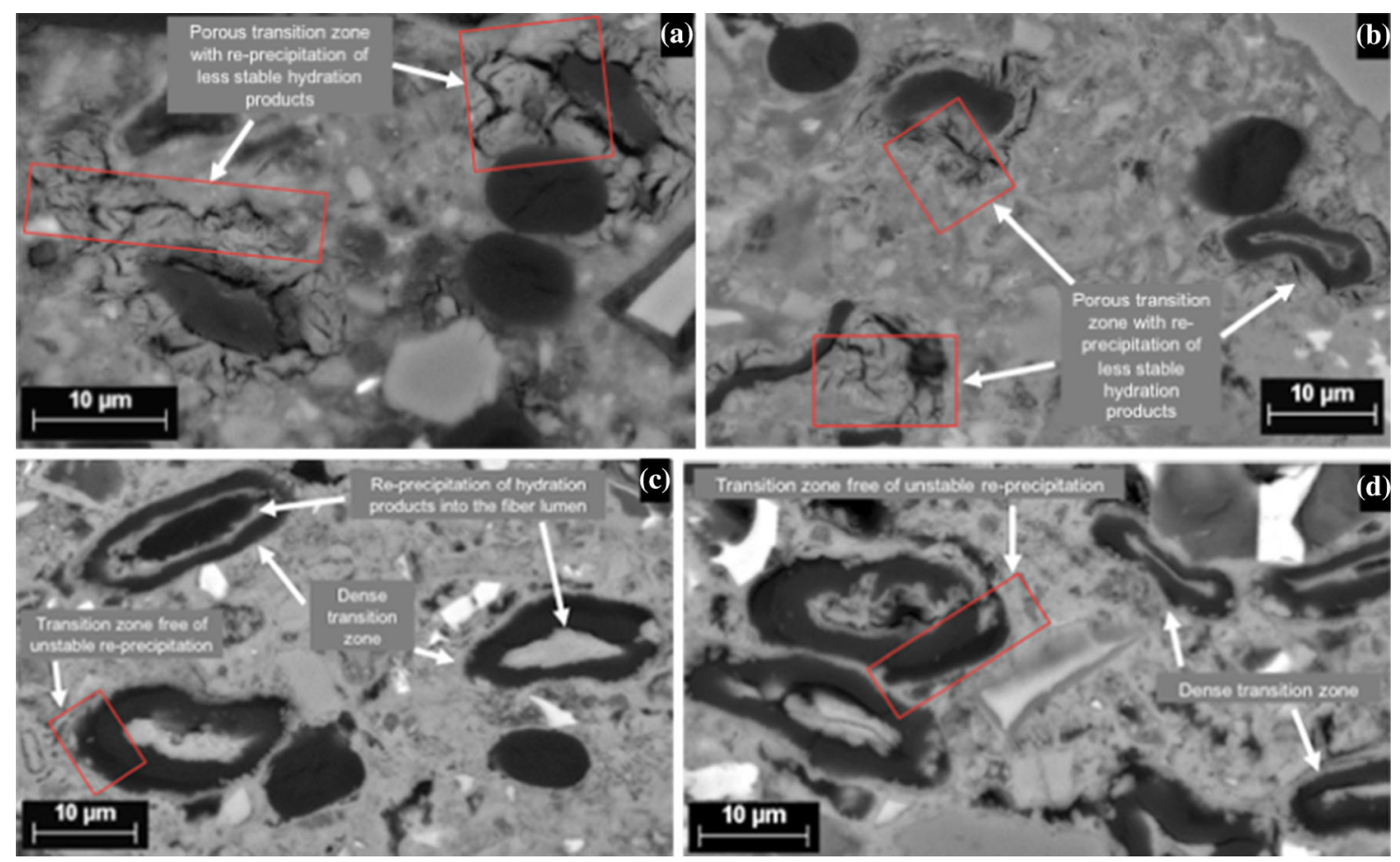

Figure 1 SEM/BSE micrographs of the cut and polished surface: a, b control (non-carbonated), arrows show porous transition zone with re-precipitation of less stable hydration products that easily

dissolved under contact with water; and c, $\mathbf{d}$ early age carbonated fiber-cement composites, arrows show a dense transition zone. Images were taken after 200 soak and dry cycles. 
carbonation was applied, and then the filling of the fibers is more evident.

\section{Changes in the hydration products due to early carbonation}

The carbonation is the reaction of cement hydration products with carbon dioxide $\left(\mathrm{CO}_{2}\right)$. The carbonation is an acid-base neutralization reaction of the alkaline nature of cement. $\mathrm{CO}_{2}$ first dissolves in the pore solution and then reacts with the $\mathrm{OH}^{-}$, forming $\mathrm{CO}_{3}{ }^{2-}$ (Eq. 1). Consequently, the $\mathrm{pH}$ of the pore solution decreases. As the solution is saturated in calcium ions, due to the $\mathrm{C}_{3} \mathrm{~S}$ and $\mathrm{C}_{2} \mathrm{~S}$ hydration, $(\mathrm{pH}$ of $12.5, \mathrm{Eq} .2$ ), the precipitation of calcium carbonate $\left(\mathrm{CaCO}_{3}\right)$ polymorphs (calcite, vaterite or aragonite) starts (Eq. 3), according to the following reactions [37]:

$$
\begin{aligned}
\mathrm{CO}_{2 \text { (gas) }}+2 \mathrm{OH}_{\text {(aqueous) }}^{-} \Leftrightarrow & \mathrm{CO}_{3 \text { (aqueous) }}^{2-}+\mathrm{H}_{2} \mathrm{O}_{\text {(liquid) }} \\
\mathrm{Ca}(\mathrm{OH})_{2 \text { (solid) }} \downarrow \Leftrightarrow \mathrm{Ca}_{\text {(aqueous) }}^{2+}+2 \mathrm{OH}_{\text {(aqueous) }}^{-} & \\
\mathrm{CO}_{2 \text { (gas) }}+\mathrm{Ca}(\mathrm{OH})_{2 \text { (solid) }} \downarrow & \mathrm{Ca}_{\text {(aqueous) }}^{2+}+\mathrm{CO}_{3 \text { (aqueous) }}^{2-} \\
& +\mathrm{H}_{2} \mathrm{O}_{\text {(liquid) }} \\
\Leftrightarrow & \mathrm{CaCO}_{3 \text { (solid) }} \downarrow+\mathrm{H}_{2} \mathrm{O}_{\text {(liquid) }}
\end{aligned}
$$

After $10 \mathrm{~h}$ of carbonation, several changes occur in the matrix structure, as observed by the SEM micrographs in the previous section. The XRD results (Fig. 2) show important changes in the cementitious phases formed in the two different curing conditions (control and early carbonated). First of all, it is observed the reduction of the amorphous background (broad band between $2 \theta=25-40^{\circ}$ ) from the control to the carbonated composite, which means an increase of the crystallinity of the phases. Calcite that is observed in the control sample (non-carbonated) is mostly due to the presence of the calcium carbonate filler in the composition. Other $\mathrm{CaCO}_{3}$ polymorphs (vaterite- $\mathrm{Va}$ and aragonite-Ar) were also detected and are result of carbonation during accelerated aging. Since natural carbonation was incomplete, calcium hydroxide (portlandite- $\mathrm{P}$ ) is detected in the control samples. Also, in lower proportion, the remaining cement anhydrous phases, such as alite $\left(\mathrm{C}_{3} \mathrm{~S}\right)$, belite $\left(\mathrm{C}_{2} \mathrm{~S}\right)$, tetracalcium aluminoferrite $\left(\mathrm{C}_{4} \mathrm{AF}\right)$, and very few traces of tricalcium aluminate $\left(\mathrm{C}_{3} \mathrm{~A}\right)$ are detected both after 10 days of standard cure and after the aging cycles. Finally, it is also observed the formation of ettringite (AFt), monocarboaluminate $(\mathrm{Mc})$, and monosulphate $(\mathrm{AFm})$ due to the presence of gypsum as a setting regulator.

The presence of $\mathrm{CO}_{2}$ during the curing period (early carbonation) led to disappearing of calcium hydroxide (portlandite-P). In the carbonated composite, it was not detected the presence of this phase, which indicates that all calcium hydroxide was converted to calcium carbonate (mostly calcite), whose XRD peaks have increased in intensity (details of the main peak for calcite in Fig. 2). $\mathrm{Va}$ and $\mathrm{Ar}$ (metastable $\mathrm{CaCO}_{3}$ polymorphs) are also detected in the carbonated composites. Apparently, more Va peaks are identified for carbonated composites, while more Ar peaks for the control composites; however, the reason is still not fully elucidated. One of the hypotheses is that the decalcification of C-S-H led to amorphous calcium carbonate until free silica was formed, and then the carbonate was converted into Ar [38]. The structure of C-S-H is very heterogeneous at the nanometric scale, so developing a complete structural model is a complex task. For simplification, C-S-H's are often categorized as types I and II, outer and inner product (OP and IP), or high density (HD) and low density (LD) C-S-H [30, 39, 40]. According to Morandeau et al. [41], CH and $\mathrm{C}-\mathrm{S}-\mathrm{H}$ become carbonated simultaneously. The initial rate of carbonation is quite similar, but while $\mathrm{C}-\mathrm{S}-\mathrm{H}$ is still carbonating, $\mathrm{CH}$ carbonation slows down and stops. This is due to the fact that $\mathrm{CH}$ becomes less and less accessible for carbonation. It has particularly been observed that C-S-H decalcification-polymerization is more pronounced at high $\mathrm{CO}_{2}$ concentration, and even that $\mathrm{C}-\mathrm{S}-\mathrm{H}$ can be completely decalcified for $\mathrm{CO}_{2}>10 \%$ [41]. However, thermodynamically $\mathrm{C}-\mathrm{S}-\mathrm{H}$ can decalcify at natural concentration of $\mathrm{CO}_{2}$ [42]. Morales-Florez et al. [40] noted that carbonation led to the precipitation of silica gel by-products of identical structure. Another prominent result of the study of these researchers is the increase in the specific surface area revealed from SAXS, which is due to the carbonation of the low density C-S-H and the precipitation of the silica gel product. In the present work, the $\mathrm{C}-\mathrm{S}-\mathrm{H}$ was not massively formed in the early carbonated composites. Then, C-S-H is more available in the non-carbonated composites, leading to the formation of Ar during natural carbonation under soak and dry cycles. Furthermore, the $\mathrm{AFt}, \mathrm{AFm}$, and Mc phases were not 
Figure 2 X-ray diffraction patterns of the control (noncarbonated) and carbonated composites before (non-aged) and after 200 soak and dry cycles (aged). $V a$ vaterite; $A r$ aragonite; $A F m$ monosulfoaluminate; AFt ettringite; $P$ portlandite; $M c$ monocarboaluminate; $C_{3} A$ tricalcium aluminate; $\mathrm{C}_{4} \mathrm{AF}$ tetracalcium aluminoferrite; $C_{2} S$ belite and $\mathrm{C}_{3} \mathrm{~S}$ alite.

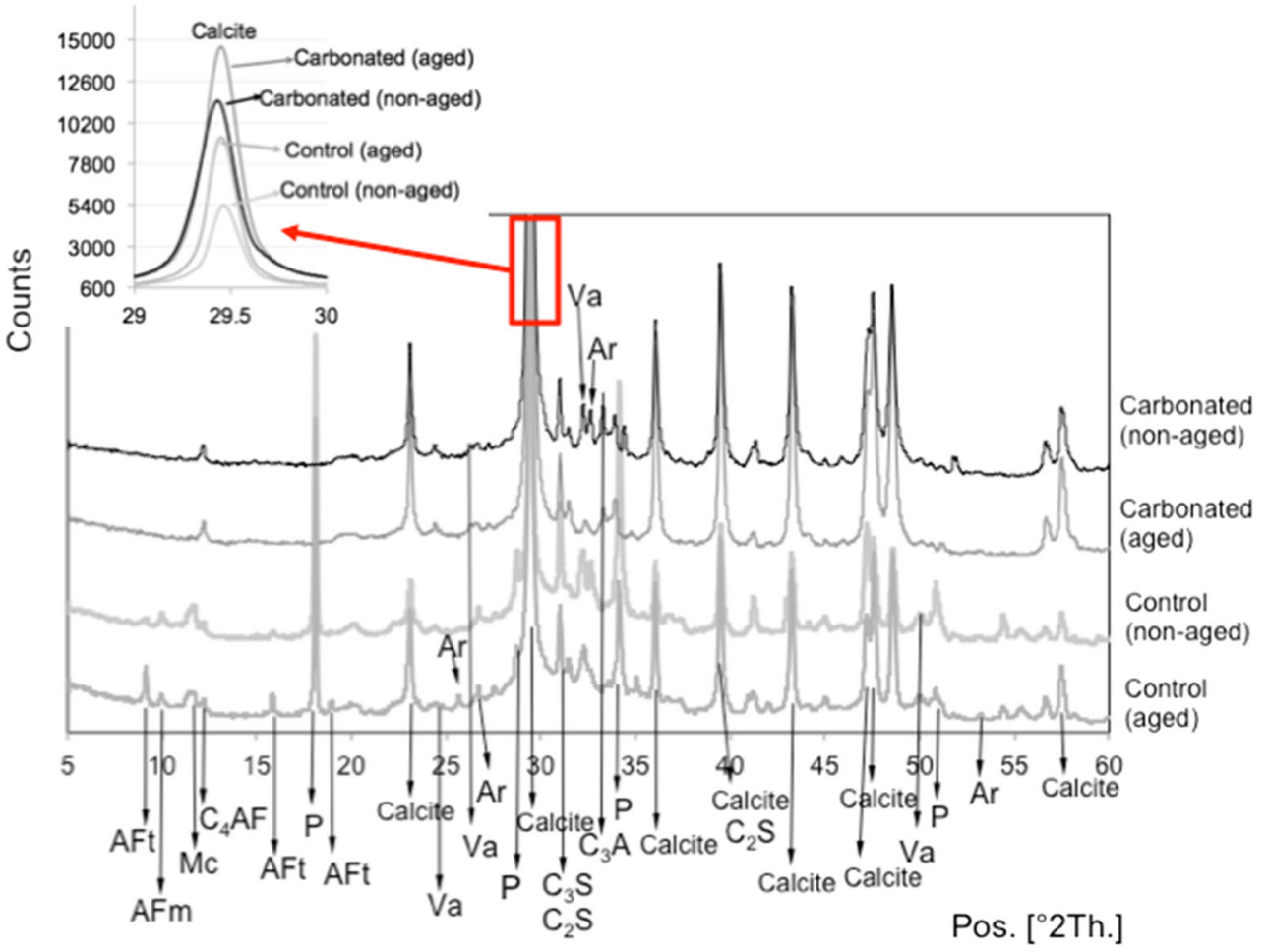

carbonated) and carbonated composites, respectively. These samples were analyzed after 200 soak and dry aging cycles. Arrows in Fig. 4a show a layer (in green) of carbonates formed on the surface (border) of the control composite during the natural carbonation occurred in the soak and dry cycles. It is obvious in this image (Fig. 4a) that the surface and the bulk of the control composite present different textures. In contrast, both the surface (border) and bulk (interior) of the carbonated composite (Fig. 5a) presents the same texture, which are formed by carbonates.

Figure $4 \mathrm{~b}-\mathrm{f}$ shows that $\mathrm{Si}$-rich phases are widely distributed in the matrix of control (non-carbonated) composite, except in the fiber transition zone. During curing and secondary hydration during aging of the control composites, the $\mathrm{Si}$ ions firstly migrate by solution diffusion to empty spaces in the bulk matrix, and less to transition zone (Fig. 4f). Those hydration ions re-precipitate in the pores (bulk or transition zone) when conditions are adequate for nucleation. In the case of the transition zone, the main hydration products reported in the literature are ettringiteAFt, monosulfoaluminate-AFm, and calcium hydroxide [44]. Figure $6 \mathrm{a}-\mathrm{c}$ shows the S- and Al-rich phases around the cellulose fibers. These hydration 


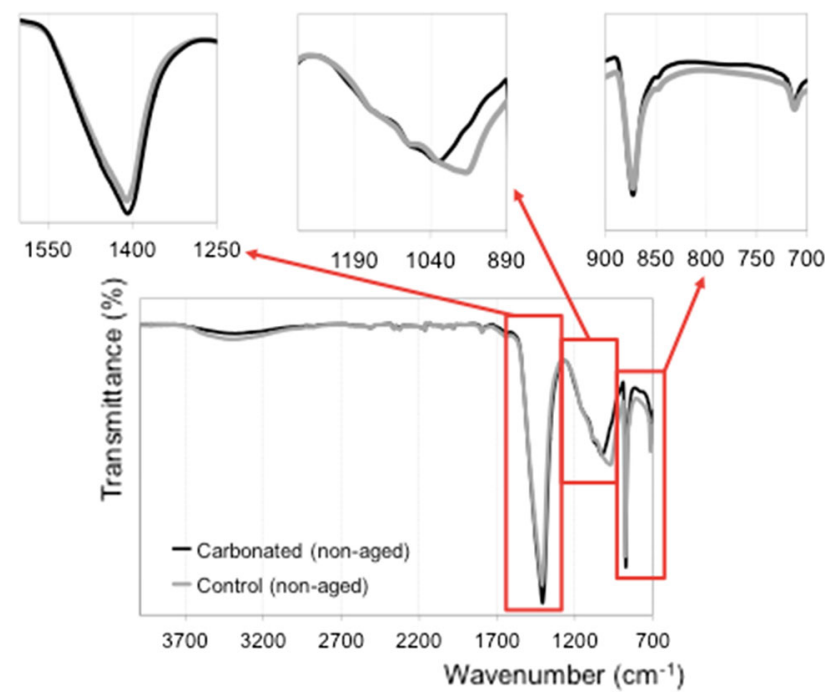

Figure 3 FTIR spectra of the control (non-carbonated) and early carbonated samples before accelerated aging.

products can also penetrate into the fiber cell wall (nucleating there when adequate conditions), and penetrate into fiber cavity (lumen), leading to the reprecipitation of ettringite/monosulphate and calcium hydroxide into the fiber. Moreover, ettringite can still be observed for moderate $\mathrm{CO}_{2}$ concentration [45]. Santos et al. [25] found different $\mathrm{Ca} / \mathrm{Si}$ ratios around the vicinity of sisal fibers in composites carbonated under supercritical conditions, when compared to non-carbonated ones.

Figure $5 b-f$ shows that $\mathrm{Si}$-rich phases are concentrated probably in the original location of alite $\left(\mathrm{C}_{3} \mathrm{~S}\right)$ and belite $\left(\mathrm{C}_{2} \mathrm{~S}\right)$ phases, with low diffusion in the matrix and in the fiber transition zone. Consequently, less $\mathrm{C}-\mathrm{S}-\mathrm{H}$ is present in those regions. The carbonation of $\mathrm{Ca}(\mathrm{OH})_{2}$ is followed by an increase in the volume of solids [46]; Silva et al. [47] show the reduction of $15 \%$ in porosity and approximately $6.5 \%$ increase in the bulk density of the composites submitted to accelerated carbonation for 14 days. $\mathrm{CaCO}_{3}$ is precipitated in the pore structure of the composite matrix, also acting as a binder, filling the voids, and thereby reducing the free intake of water due to the decrease of pore size [48]. Then, these pores become almost closed instead of the initially predominant capillary pores, and less permeable to silicates, so decreasing diffusion of $\mathrm{Si}$ and $\mathrm{S}$ ions during curing and secondary hydration. Figure $7 \mathrm{a}-\mathrm{C}$ shows that $\mathrm{S}$ is widely distributed in the carbonated matrix, while Al-rich phases are concentrated in the
$\mathrm{C}_{3} \mathrm{~A}$ (tricalcium aluminate) or $\mathrm{C}_{4} \mathrm{AF}$ (tetracalcium aluminoferrite) anhydrous grains, and have not been solubilized and re-precipitated around the cellulose fibers. Therefore, less Aft, Afm, and Mc phases are formed in the transition zone around the fibers because of the lower diffusion of S- and Al-rich phases. These S-rich phases are responsible for peeling off cellulose chains, degrading its structure at long term. Furthermore, it is known that the carbonates formation leads to the decrease of the alkalinity of the matrix [49], and therefore providing a less aggressive environment to the cellulose fibers. The chemical stability of the carbonated hydration products is also an important advantage [13] for the macroscopic performance of the material.

Figures $6 \mathrm{~d}$ and $7 \mathrm{~d}$ depict the differential weight loss (DTG) of the composites at the different carbonation conditions, before and after aging. Endothermic events can be identified in the three main zones of decomposition: $50-250{ }^{\circ} \mathrm{C}$ (hydrated phases: C-S-H, AFm, Mc, and Aft), $400-450{ }^{\circ} \mathrm{C}$ $\left(\mathrm{Ca}(\mathrm{OH})_{2}\right.$ or portlandite- $\left.\mathrm{P}\right)$, and $500-850{ }^{\circ} \mathrm{C}$ (stable and less stable carbonates).

The changes in the weight loss between 90 and $200{ }^{\circ} \mathrm{C}$ correspond to the interaction of $\mathrm{C}-\mathrm{S}-\mathrm{H}$, ettringite $\left(\mathrm{C}_{3} \mathrm{AS}_{3} \mathrm{H}_{32}-\mathrm{AFt}\right)$, monosulfoaluminate $\left(\mathrm{C}_{3} \mathrm{ASH}_{12}-\mathrm{AFm}\right)$, and monocarboaluminate $\left(\mathrm{C}_{4} \mathrm{AcH}_{11}-\mathrm{Mc}\right)$ with $\mathrm{CO}_{2}$ as also observed by Almeida et al. [50, 51] and Frías et al. [37] adopting different curing conditions and cementing matrices. These results indicate that the carbonation rate occurred in a high extension, reducing by $58 \%$ the weight loss in the range between 50 and $250{ }^{\circ} \mathrm{C}$ of the carbonated composites. The $\mathrm{C}-\mathrm{S}-\mathrm{H}$ is progressively decalcified, being converted to $\mathrm{CaCO}_{3}$ and S-H (silica hydrates). Dissolution of $\mathrm{Ca}(\mathrm{OH})_{2}$ generally takes place more readily, while decalcification of $\mathrm{C}-\mathrm{S}-\mathrm{H}$ occurs when $\mathrm{Ca}(\mathrm{OH})_{2}$ is inaccessible or locally reduced. Nevertheless, when the porosity in the fiber-cement is sufficiently high to permit constant $\mathrm{CO}_{2}$ diffusion, the $\mathrm{Ca}(\mathrm{OH})_{2}$ is further reduced and the calcium from $\mathrm{C}-\mathrm{S}-\mathrm{H}$ also reacts with carbon dioxide [52].

The temperature range between 295 and $370{ }^{\circ} \mathrm{C}$ corresponds to the degradation of the cellulose fibers, and no changes were observed between the tested conditions. Figure $6 \mathrm{~d}$ also shows the changes in the endothermic peaks between 450 and $500{ }^{\circ} \mathrm{C}$ related to the decomposition of the $\mathrm{Ca}(\mathrm{OH})_{2}$. The mass loss in this range decreases as the carbonation occurs. No 

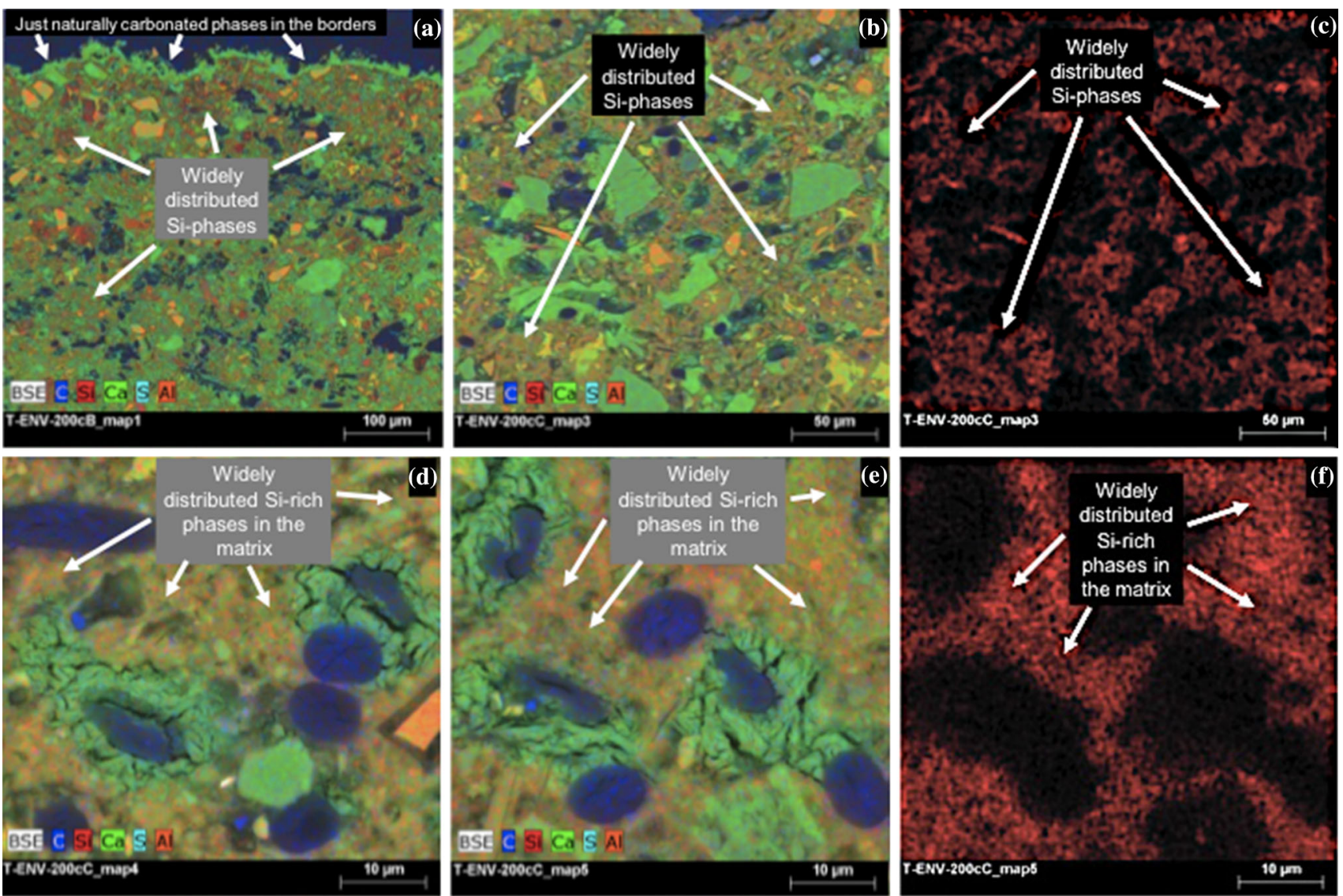

Figure 4 SEM/BSE micrographs of the cut and polished surface control (non-carbonated) fiber-cement composites after 200 soak and dry aging cycles: $\mathbf{a}, \mathbf{b}, \mathbf{d}$, e colored EDS mapping for $\mathrm{C}, \mathrm{Si}$, $\mathrm{Ca}, \mathrm{S}$, and $\mathrm{Al}$; c, $\mathbf{f}$ EDS mapping just for $\mathrm{Si}$ (c) was taken in the same region of (b), while (f) was taken in the same region of (e).

mass loss at this temperature range was observed for the carbonated sample (Fig. 7d). Finally, the accelerated carbonation increased the mass loss at the range between 500 and $850{ }^{\circ} \mathrm{C}$, which are related to the carbonates. Carbonation increases the mass loss between 500 and $750{ }^{\circ} \mathrm{C}$ related to the thermal decomposition of poorly crystallized $\mathrm{CaCO}_{3}$ polymorphs and at the range between 750 and $850{ }^{\circ} \mathrm{C}$ related to decomposition of the well-crystallized $\mathrm{CaCO}_{3}$, as also reported by Rostami et al. [53]. According to Thiery et al. [54], the well-crystallized calcite decomposes between 780 and $990{ }^{\circ} \mathrm{C}$, and the presence of vaterite and aragonite causes the carbonates to decompose at lower temperatures $\left(680-780^{\circ} \mathrm{C}\right)$, while decomposition between 550 and $680{ }^{\circ} \mathrm{C}$ is probably associated with amorphous calcium carbonate. The decomposition ranging between 500 and $850{ }^{\circ} \mathrm{C}$ for non-carbonated (control)
Arrows in (a) show the layer of carbonates formed on the composite surface (border) during natural carbonation. Arrows also show the Si-rich phases widely distributed in the bulk of the fiber-cement matrix.

composites is related in great part to the carbonate content in the as-received cement and calcium carbonate content from calcareous filler, the supplementary material applied in the fiber-cement formulation, in order to reduce production costs.

The 200 soak and dry cycles decreased the content of hydrated phases (AFt, AFm, Mc, and C-S-H) and mainly of portlandite $\left[\mathrm{Ca}(\mathrm{OH})_{2}\right]$ in the case of the control non-carbonated sample. This decrease is resultant of the natural carbonation occurred during the drying stage of the accelerated aging cycles. The carbonated samples before (non-aged) and after (aged) soak and dry cycles showed an important increase of carbonates content $\left(\mathrm{CaCO}_{3}\right)$ in relation to non-aged and aged control samples (non-carbonated). As commented above, the soak and dry aging cycles increased the carbonate content in all the conditions tested, due to the natural carbonation 

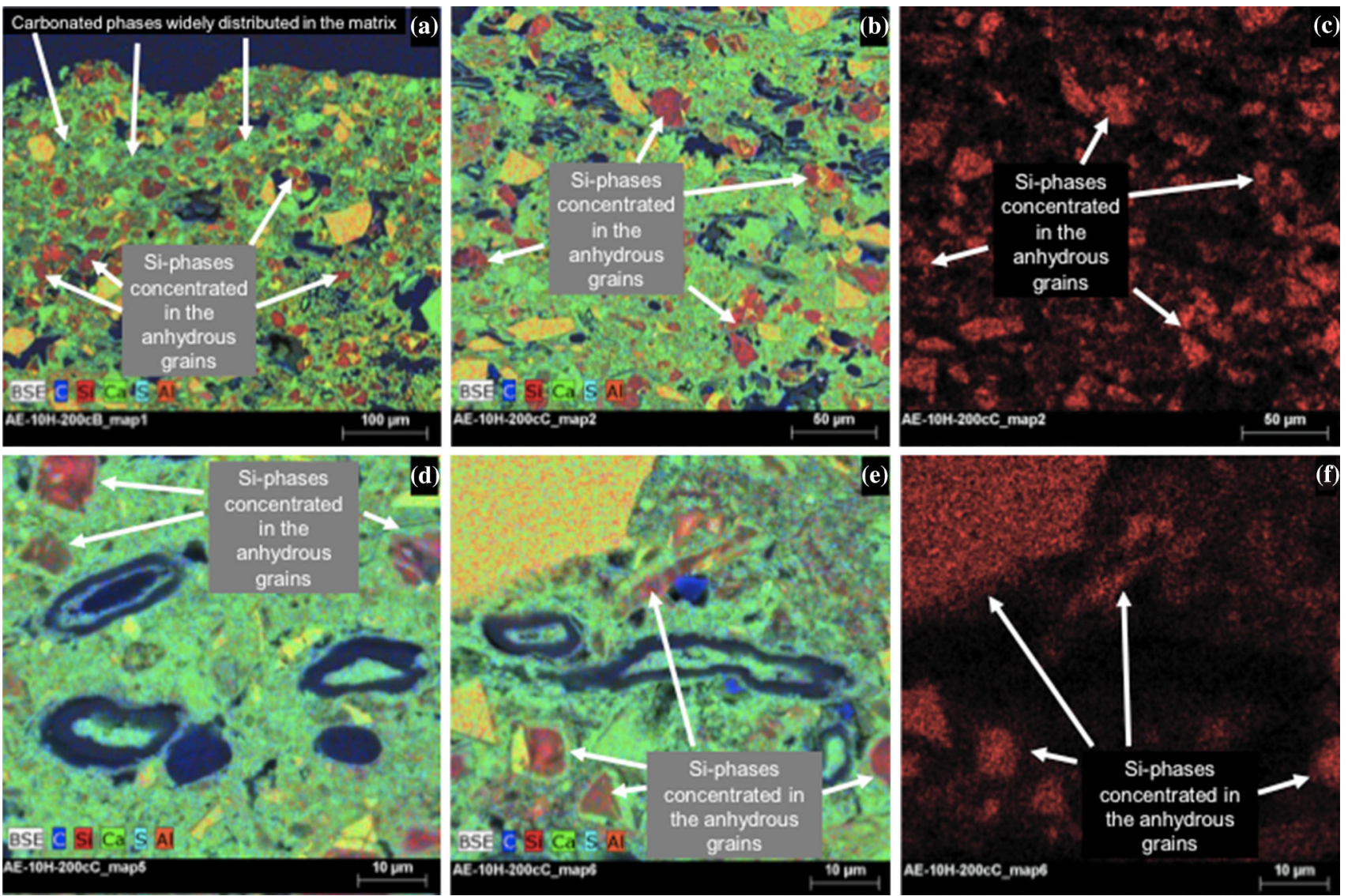

Figure 5 SEM/BSE micrographs of the cut and polished surface of early carbonated fiber-cement composites after 200 soak and dry aging cycles: $\mathbf{a}, \mathbf{b}, \mathbf{d}$, e colored EDS mapping for $\mathrm{C}, \mathrm{Si}, \mathrm{Ca}, \mathrm{S}$, and $\mathrm{Al}$; c, f EDS mapping just for Si. (c) was taken in the same region of (b), while (f) was taken in the same region of (e).

during the atmospheric air exposition in the drying stage of the aging cycles. Additionally, Figs. $6 \mathrm{~d}$ and $7 \mathrm{~d}$ show that both early carbonation and soak and dry cycles increased the temperature of maximum decomposition of the carbonates (from around 730 to $\left.770{ }^{\circ} \mathrm{C}\right)$.

Arrows in Fig. 6e, f show needles of AFt formed in the matrix pores and around the cellulose fibers before and after soak and dry cycles of the control (non-carbonated) composites, respectively. This was particularly evident in the EDS semi-quantitative analysis reported in previous work [21], where sulfur (S) is present, with high S:Ca ratio (between 0.06 and 0.22) and Ca:Si ratio (between 12 and 40). The needles were not observed in the accelerated carbonated composites (Fig. 7e, f). In this case, the microstructure is compact and formed by layered structures (arrows in Fig. 7e, f), probably related to
Arrows in (a) show that the carbonates are widely distributed in the bulk of the composites. Arrows also show the Si-rich phases are concentrated in the alite $\left(\mathrm{C}_{3} \mathrm{~S}\right)$ and belite $\left(\mathrm{C}_{2} \mathrm{~S}\right)$ anhydrous grains.

the $\mathrm{CaCO}_{3}$ polymorph phases, where very little content of $\mathrm{S}$ is detected. S:Ca ratio was between 0.0006 and 0.03 and Ca:Si ratio around the cellulose fibers is much lower (between 2 and 4) in the carbonated composites [21]. Then, $\mathrm{S}$ remains widely distributed in the water pore in the carbonated matrix (Fig. $7 \mathrm{~b}$ ) instead of concentrated in the transition zone, as observed for non-carbonated (Fig. 6b). Also, the Ca:Si ratio around the cellulose fibers in the non-carbonated fiber-cement was between 12 and 40. Figure 7e, f shows rhombohedral profiles of calcareous filler and packed/layered nanocrystals of calcite formed by carbonation can also be identified. These results are in agreement with the lower (or null) content of $\mathrm{Ca}(\mathrm{OH})_{2}, \mathrm{C}-\mathrm{S}-\mathrm{H}$, $\mathrm{AFt}, \mathrm{AFm}$ and Mc observed in the patterns (Fig. 2) and weight loss (DTG-Fig. 7d) of the early carbonated composites. 

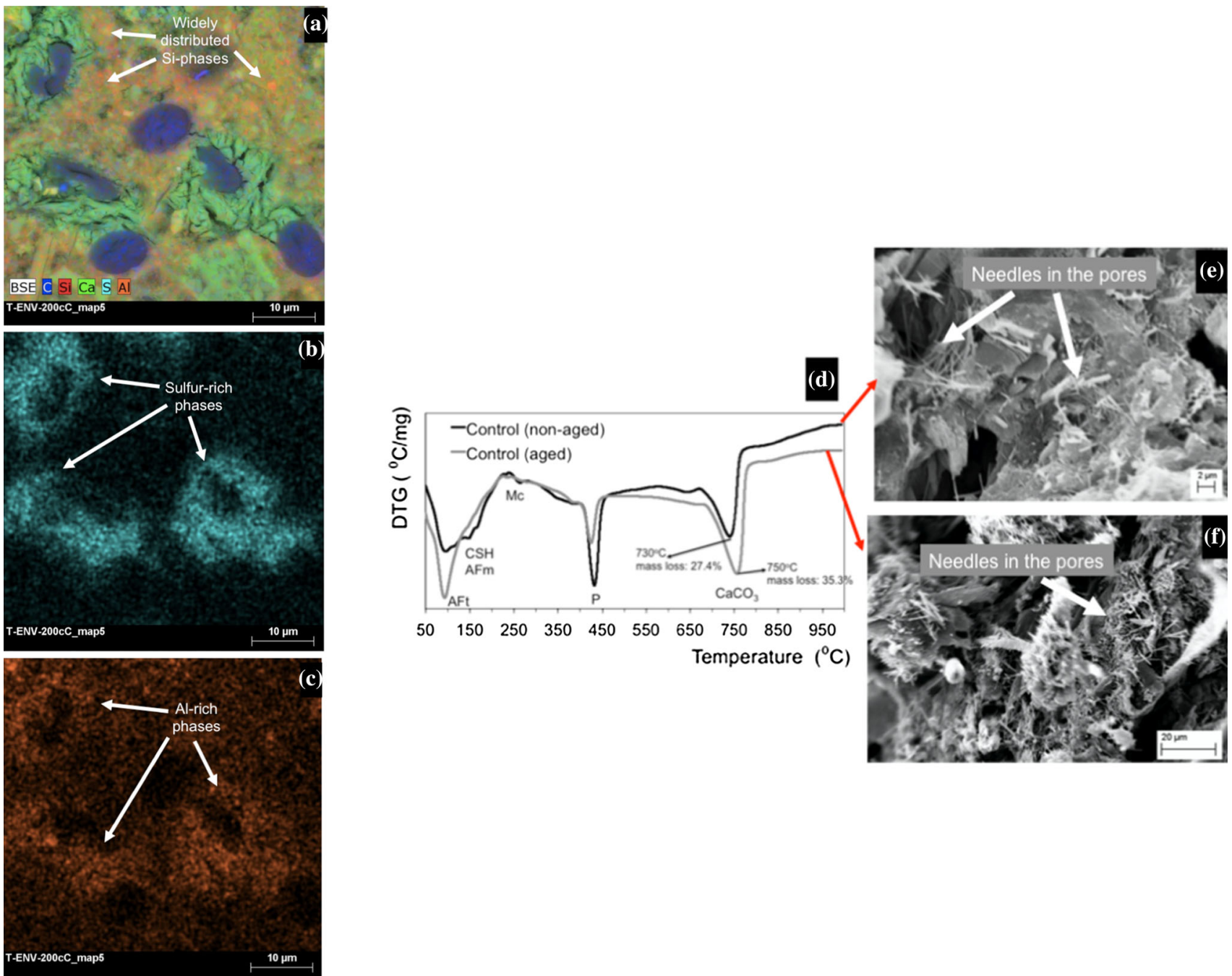

Figure 6 a, b, c SEM/BSE micrographs with EDS mapping of the cut and polished surface of the control (non-carbonated) fibercement composites. a EDS mapping for $\mathrm{C}, \mathrm{Si}, \mathrm{Ca}, \mathrm{S}$, and $\mathrm{Al} ; \mathbf{b}$ just for S; and $\mathrm{c}$ just for Al. All these SEM/BSE images were taken in the same region. Arrows show the S- and Al-rich phases localized at the transition zone of the cellulose fibers. d DTG of control

Figure 8 shows a schematic illustration of the fiber-matrix transition zone in the control (non-carbonated) and in the early carbonated composites. In the control condition (non-carbonated, Fig. 8a), it is supposed that the mineralization of the cellulose fibers is higher and caused by the free ions from the saturated curing and secondary hydration of Portland cement that: (1) firstly migrate by solution diffusion to empty spaces in the bulk matrix and transition zone; (2) re-precipitate in those pores when conditions are adequate for nucleation; (3) penetrate into the fiber cell wall (nucleating there in composites before and after soak and dry aging AFt ettringite; AFm monosulfoaluminate; $P$ portlandite; $C-S-H$ calcium silicate hydrate; $\mathrm{Mc}$ monocarboaluminate; and $\mathrm{CaCO}_{3}$ calcium carbonate polymorphs. e, f SEM/SE of the fractured surface of control composites-arrows show the needles (probably AFt).

the occurrence of adequate conditions); (4) penetrate into fiber cell wall; and (5) penetrate into the fiber cavity (lumen), leading in some cases to the re-precipitation of different alkaline solid phases into the fiber when conditions are appropriate. This re-precipitation of solids into the fiber voids (both fiber cell wall and fiber lumen) induces the embrittlement of the cellulose fibers by the attack of released alkaline's ions. Secondary (re-precipitated) ettringite (AFt) formation has been previously suggested as one of the degradation mechanisms of pulp fiber into cement matrix $[4,5]$. 

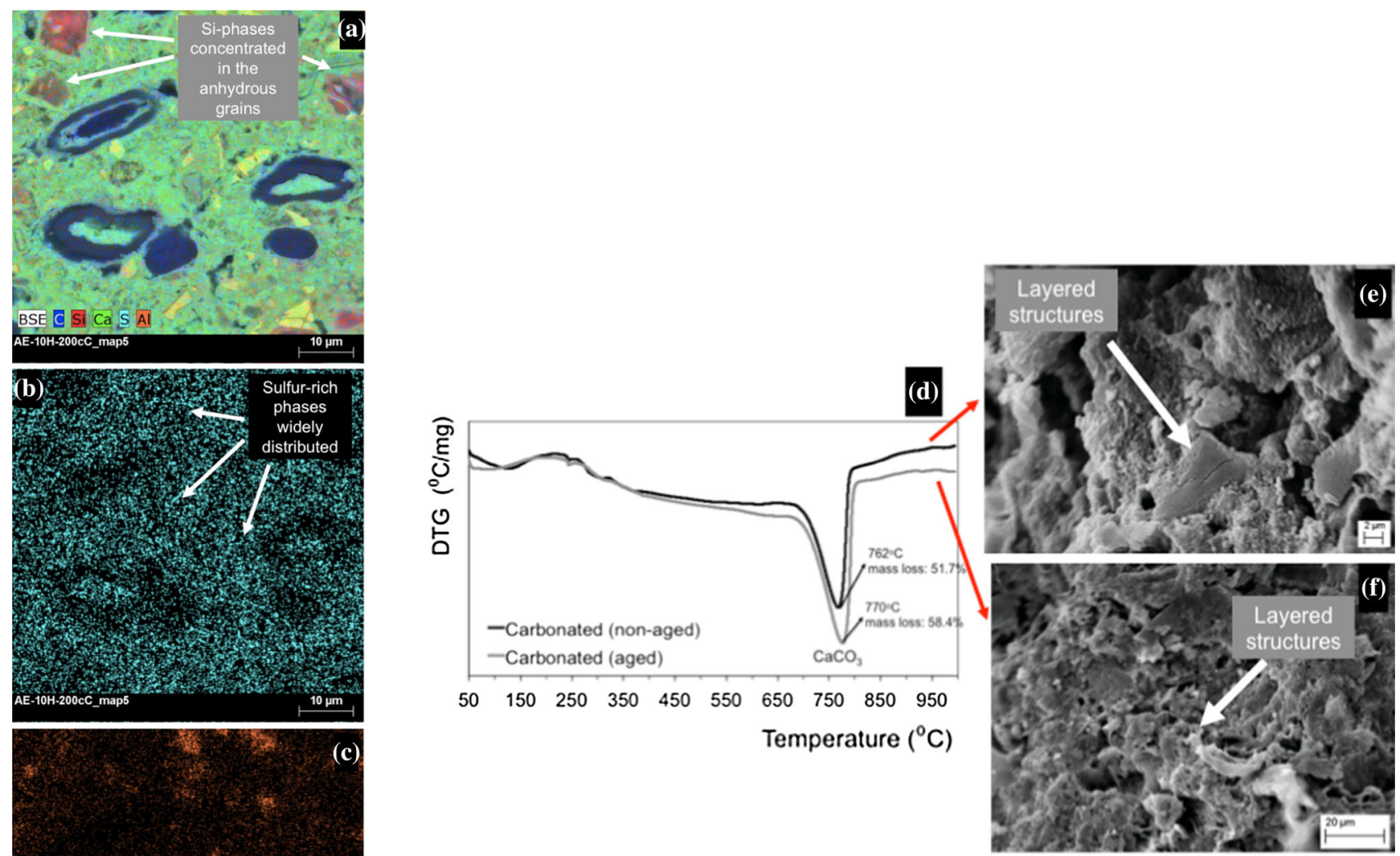

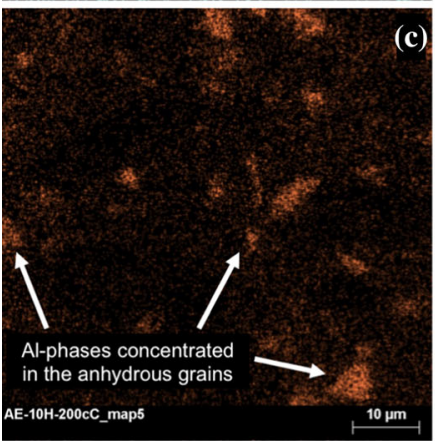

Figure 7 a, b, c SEM/BSE micrographs with EDS mapping of the cut and polished surface of the early carbonated fiber-cement composites. a EDS mapping for $\mathrm{C}, \mathrm{Si}, \mathrm{Ca}, \mathrm{S}$ and $\mathrm{Al}$; $\mathbf{b}$ just for $\mathrm{S}$; and $\mathrm{c}$ just for Al. All these SEM/BSE images were taken in the same region. Arrows show the $\mathrm{S}$ widely distributed and Al-rich phases concentrated in the $\mathrm{C}_{3} \mathrm{~A}$ (tricalcium aluminate) or $\mathrm{C}_{4} \mathrm{AF}$

In this hypothesis, the $\mathrm{CaCO}_{3}$ polymorphs were precipitated in the pore structure of the carbonated matrix, filling the voids and thereby reducing the intake of free water and other hydration products as opposed of the initial pores (Fig. 8b). These closed pores decrease permeability and diffusion of $\mathrm{Si}, \mathrm{S}$, and $\mathrm{Al}$ ions during the curing and secondary hydration. Consequently, less AFt phase is formed around the fibers because of lower diffusion of S- and Al-rich phases, as confirmed by FTIR analysis with the decrease of asymmetric stretching of $\mathrm{SO}_{4}{ }^{2-}$ groups.

In carbonated composites, the greater adhesion between the cement and the cellulose fiber in (tetracalcium aluminoferrite) anhydrous grains. d DTG of control composites before and after soak and dry aging cycles; $\mathrm{CaCO}_{3}=$ calcium carbonate polymorphs. e, f SEM/SE of the fractured surface of control composites-arrows show the layered carbonates.

conjunction with the intensive lumens filled with the carbonated products may lead one to expect the embrittlement of the composite. However, our hypothesis is that the fiber cell wall in carbonated composites would be less attacked by the alkaline ions, resulting in lower mineralization of the fiber cell wall.

\section{Consequences of the early carbonation on drying shrinkage}

When the relative humidity decreases the porous materials undergo a so-called drying shrinkage. Indeed, the evaporation of the interstitial liquid water 
Figure 8 Schematic illustration of the cellulose fiber and matrix interface: a control (non-carbonated); and $\mathbf{b}$ carbonated. Details of the flow of hydration products and re-precipitations. AFt ettringite; $A F m$ monosulfoaluminate; $M c$ monocarboaluminate; and $\mathrm{CH}$ portlandite; $A V V$ apparent void volume.
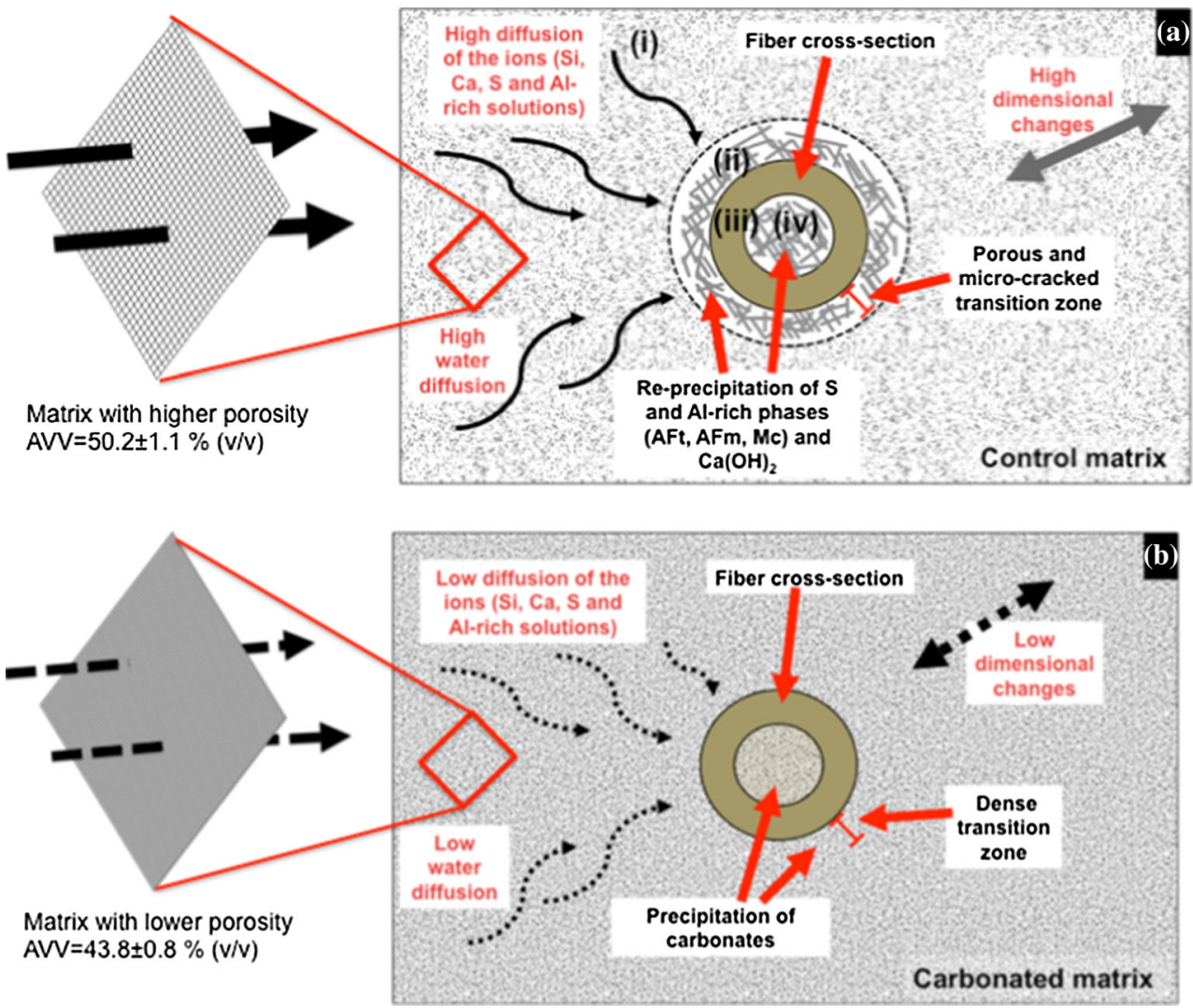

and the consequent decrease of the liquid saturation give rise to capillary pressure effects that lead to contraction of the solid structure of the composite [55]. Figure 9 presents the length variation $(\mathrm{mm} / \mathrm{m})$ of the composites in relation to the initial condition (saturated water vapor). Specimens were submitted to the first drying after 10 days of total curing. The length values of the composites decrease in relation to the initial condition (water vapor saturated). Carbonated composites presented lower drying shrinkage than control composites. The smaller pores in carbonated composites increase interfacial energy during drying shrinkage as relative humidity is reduced in relation to the initial condition. Carbonated composites in this condition present smaller water absorption (WA) and higher bulk density (BD) than control composites (Fig. 9). The cement matrix of the carbonated composite is denser and compact, what improves the contact between the fibers and cement matrix to form a rigid structure with lower drying shrinkage. In the opposite (for control), the large porosity provokes large loosing of water, which leads to great volume change in the microstructure of the non-carbonated composite. The decrease of
C-S-H inner porosity in carbonated composites must reduce shrinkage. Furthermore, S-rich phases are known to present an expansive behavior when in contact with water, which is prejudicial for the stability of the fiber transition zone. In some cement products, excessive amounts of formed ettringite may cause expansion and cracking of the hardened paste and must be avoided. On the other hand, in some expansive cements, the formation of ettringite is employed to generate desired expansive stresses [56]. Additionally, the crystallization of ettringite in noncarbonated composites can lead to microcrackings, which propagate in a complex manner due to the non-uniform nature of the composite matrix formed by the cement [57].

\section{Conclusion}

Early age carbonation is presented as an interesting strategy to prematurely decrease the alkalinity of the cement matrix by consumption of ions $\mathrm{Ca}^{2+}$ and $\mathrm{OH}^{-}$ in the pore solution. $\mathrm{C}-\mathrm{S}-\mathrm{H}, \mathrm{AFm}, \mathrm{AFt}$, and Mc were 


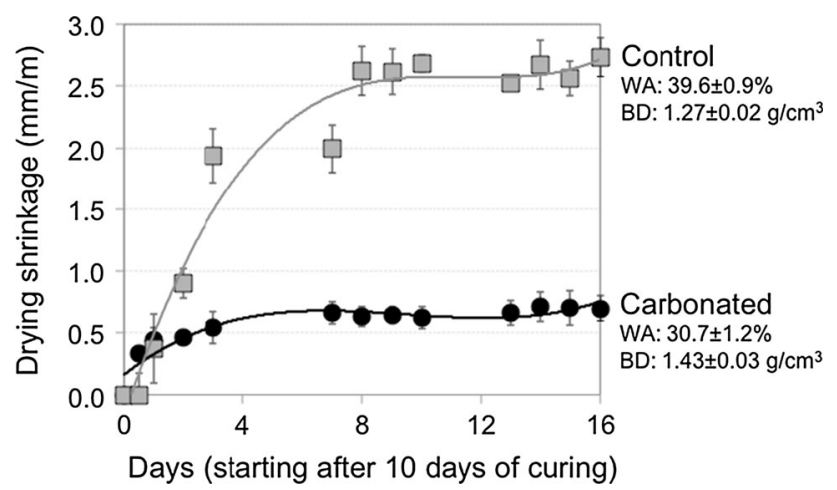

Figure 9 Drying shrinkage, water absorption (WA), and bulk density (BD) of the control (non-carbonated) and carbonated composites.

not observed during this carbonation process. $\mathrm{CaCO}_{3}$ polymorphs were observed filling the voids and the pore structure of the carbonated matrix, which resulted in the densification of the matrix. In the carbonated composites, the Si-rich phases are still concentrated in the alite $\left(C_{3} S\right)$ and belite $\left(C_{2} S\right)$ regions, with low diffusion in the matrix and in the fiber transition zone. Therefore, matrix becomes more chemically stable with lower diffusion of ions from curing and secondary hydration. It improves the contact between fibers and cement matrix and thus preventing the movement of water due to the decrease in the pore size network and diffusion of degradation products (e.g., $\mathrm{Ca}$ and $\mathrm{S}$ ions) into the composite. In the control (non-carbonated) matrix, the $\mathrm{Si}$ ions migrate by solution diffusion and re-precipitate in the empty spaces in the bulk matrix, while less to transition zone. Otherwise, the presence of $\mathrm{S}$ - and Al-rich products in the fiber-matrix transition zone was particularly evident in the EDS mapping of the non-carbonated composites. The S- and Al-rich needles (probably related to the AFt and AFm phases) were not seen in the early carbonated composites, and $\mathrm{S}$ was detected in very low content concentrated around the cellulose fibers. Additionally, another consequence of carbonation at early age is the volume stabilization, as indicated by the lower drying shrinkage and lower porosity. Early age carbonation can be a successful procedure to mitigate the degradation of cellulose fibers in fiber-cement composites exposed to weathering. The current results also encourage the fiber-cement production with partial replacement of the plastic (e.g., polypropylene and polyvinyl alcohol) fibers by cellulose pulp fibers.

\section{Acknowledgements}

Thanks to Conselho Nacional de Desenvolvimento Científico e Tecnológico (CNPq), Fundação de Amparo à Pesquisa do Estado de São Paulo (FAPESP Process nos. 2012/51467-3; 2013/50790-8; 2013/23810-8; i-LINK program between CSIC and FAPESP Grant nos. 2013/50790-8 and i-Link0675-2013), Fundação de Amparo à Pesquisa do Estado de Minas Gerais (FAPEMIG), Coordenação de Aperfeiçoamento de Pessoal de Nível Superior (Capes), Infibra S. A., Imbralit Ltda., Research Nucleus on Materials for Biosystems - Biosmat (FZEA/USP), and Rede Brasileira de Compósitos e Nanocompósitos Lignocelulósicos (RELIGAR), in Brazil. Thanks also to the collaboration agreement between the University of São Paulo (FZEA/USP, Brazil) and the State Agency for National Research Council (IETccCSIC, Spain) that benefited this present partnership.

\section{References}

[1] Ikai S, Reichert JR, Rodrigues AV, Zampieri VA (2010) Asbestos-free technology with new high toughness polypropylene (PP) fibers in air-cured Hatschek process. Constr Build Mater 24(2):171-180

[2] Ardanuy M, Claramunt J, Toledo Filho RD (2015) Cellulosic fiber reinforced cement-based composites: a review of recent. Constr Build Mater 79:115-128

[3] Hakamy A, Shaikh FUA, Low IM (2015) Thermal and mechanical properties of $\mathrm{NaOH}$ treated hemp fabric and calcined nanoclay-reinforced cement nanocomposites. Mater Des 80:70-81

[4] Mohr BJ, Nanko H, Kurtis KE (2005) Durability of Kraft pulp fiber-cement composites to wet/dry cycling. Cem Concr Compos 27(4):435-448

[5] Mohr BJ, Biernacki JJ, Kurtis KE (2006) Microstructural and chemical effects of wet/dry cycling on pulp fiber-cement composites. Cem Concr Res 36:1240-1251

[6] Tonoli GHD, Savastano H Jr, Fuente E, Negro C, Blanco A, Rocco Lahr LA (2010) Eucalyptus pulp fibres as alternative reinforcement to engineered cement-based composites. Ind Crop Prod 31:225-232

[7] Tonoli GHDT, Rodrigues Filho UP, Savastano H Jr, Bras J, Belgacem MN, Rocco Lahr FA (2009) Cellulose modified fibres in cement based composites. Compos Part A 40(12):2046-2053

[8] Tonoli GHD, Santos SF, Savastano H Jr, Delvasto S, Mejía de Gutiérrez R, Lopez de Murphy MM (2011) Effects of natural weathering on microstructure and mineral 
composition of cementitious roofing tiles reinforced with fique fibre. Cem Concr Compos 33(2):225-232

[9] Tonoli GHD, Belgacem MN, Bras J, Pereira-da-Silva MA, Lahr FAR, Savastano H Jr (2012) Impact of bleaching pine fibre on the fibre/cement interface. $J$ Mater Sci 47:4167-4177

[10] Rostami V, Shao Y, Boyd AJ (2012) Carbonation curing versus steam curing for precast concrete production. J Mater Civ Eng 24:1221-1229

[11] Lin X (2007) Effect of early age carbonation on strength and $\mathrm{PH}$ of concrete. M. Eng Thesis, McGill University, Canada, p 119

[12] Rostami V, Shao Y, Boyd AJ, He Z (2012) Microstructure of cement paste subject to early carbonation curing. Cem Concr Res 42:186-193

[13] Soroushian P, Won J-P, Hassan M (2012) Durability characteristics of $\mathrm{CO}_{2}$-cured cellulose fiber reinforced cement composites. Constr Build Mater 34:44-53

[14] Fernández-Carrasco L, Torréns-Martín D, Martínez-Ramírez S (2012) Carbonation of ternary building cementing materials. Cem Concr Compos 34:1180-1186

[15] Ogino T, Suzuki T, Sawada K (1987) The formation and transformation mechanism of calcium carbonate in water. Geochim Cosmochim Acta 51:2757-2767

[16] Gopi S, Subramanian VK, Palanisamy K (2013) Aragonitecalcite-vaterite: a temperature influenced sequential polymorphic transformation of $\mathrm{CaCO}_{3}$ in the presence of DTPA. Mater Res Bull 48:1906-1912

[17] Taft H (1967) Carbonate rocks. In: Chilingar GV, Bissell HJ, Fairbridge RW (eds) Developments in sedimentology, vol 3, 99th edn. Elsevier, Amsterdam, pp 151-167

[18] Yamaguchi T, Murakawa K (1981) Preparation of spherical $\mathrm{CaCO}_{3}$, (vaterite) powder transition to calcite in water. Zairyo 30:856-860

[19] Tzotzi C, Pahiadaki T, Yiantsios SG, Karabelas AJ, Andritsos N (2007) A study of $\mathrm{CaCO}_{3}$ scale formation and inhibition in RO and NF membrane processes. J Membr Sci 296:171-184

[20] Toledo Filho RD, England GL, Ghavami K, Scrivener K (2003) Development of vegetable fibre-mortar composites of improved durability. Cem Concr Compos 25:185-196

[21] Pizzol VD, Mendes LM, Savastano H Jr, Frias M, Davila FJ, Cincotto MA, John VM, Tonoli GHD (2014) Mineralogical and microstructural changes promoted by accelerated carbonation and ageing cycles of hybrid fiber-cement composites. Constr Build Mater 68:750-756

[22] Lesti M, Tiemeyer C, Plank J (2013) $\mathrm{CO}_{2}$ stability of Portland cement based well cementing systems for use on carbon capture and storage (CCS) wells. Cem Concr Res 45: $45-54$
[23] Tonoli GHD, Santos SF, Joaquim AP, Savastano H Jr (2010) Effect of accelerated carbonation on cementitious roofing tiles reinforced with lignocellulosic fibre. Constr Build Mater 24:193-201

[24] Santos SF, Schmidt R, Almeida AEFS, Tonoli GHD, Savastano H Jr (2015) Supercritical carbonation treatment on extruded fibre-cement reinforced with vegetable fibres. Cem Concr Compos 56:84-94

[25] Dias CMR, Savastano H Jr, John VM (2010) Exploring the potential of functionally graded materials concept for the development of fiber cement. Constr Build Mater 24(2):140-146

[26] Associação Brasileira de Normas Técnicas (1991) NBR 11578: Cimento Portland Composto. Rio de Janeiro, p 1453

[27] Pizzol VD, Mendes LM, Frezzatti L, Savastano H Jr, Tonoli GHD (2014) Effect of accelerated carbonation on the microstructure and physical properties of hybrid fiber-cement composites. Miner Eng 59:101-106

[28] European Standard, EN 494 (1994) Fibre-cement profiled sheets and fittings for roofing-products specification and test methods

[29] Tonoli GHD, Santos SF, Teixeira RS, Pereira-da-Silva MA, Lahr FAR, Pescatori Silva FH, Savastano H Jr (2013) Effect of eucalyptus pulp refining on the performance and durability of fibre-cement composites. J Trop For Sci 25(3):400-409

[30] Taylor HFW (1997) Cement chemistry, 2nd edn. Thomas Telford Pub, London

[31] Hoppe Filho J (2008) Sistemas cimento, cinza volante e cal hidratada: mecanismo de hidratação, microestrutura e carbonatação de concreto. Tese (Doutorado em Engenharia Civil)_Escola de Engenharia, Universidade de São Paulo, São Paulo (in Portuguese)

[32] American Society for Testing and Materials. ASTM C 948-81 (2009) Test method for dry and wet bulk density, water absorption, and apparent porosity of thin sections of glass-fiber reinforced concrete. West Conshohocken, PA, USA

[33] Associação Brasileira de Normas Técnicas (2007) NBR 15498: placa plana cimentícia sem amianto, requisitos e métodos de ensaio. Rio de Janeiro 26:453

[34] Savastano H Jr, Agopyan V (1999) Transition zone studies of vegetable fibre-cement paste composites. Cem Concr Compos 21:49-57

[35] Farahi E, Purnell P, Short NR (2013) Supercritical carbonation of calcareous composites: influence of curing. Cem Concr Compos 43:48-53

[36] Farahi E, Purnell P, Short NR (2013) Supercritical carbonation of calcareous composites: influence of mix design. Cem Concr Compos 43:12-19 
[37] Frías M, Goñi S (2013) Accelerated carbonation effect on behavior of ternary Portland cements. Compos B 48:122-128

[38] Black L, Garbev K, Gee I (2008) Surface carbonation of synthetic $\mathrm{C}-\mathrm{S}-\mathrm{H}$ samples: a comparison between fresh and aged $\mathrm{C}-\mathrm{S}-\mathrm{H}$ using X-ray photoelectron spectroscopy. Cem Concr Res 38(6):745-750

[39] Jennings HM (2008) Refinements to colloid model of C-S$\mathrm{H}$ in cement: CM-II. Cem Concr Res 38(3):275-289

[40] Morales-Florez V, Findling N, Brunet F (2012) Changes on the nanostructure of cementitius calcium silicate hydrates (C-S-H) induced by aqueous carbonation. J Mater Sci 47:764-771

[41] Morandeau A, Thiéry M, Dangla P (2014) Investigation of the carbonation mechanism of $\mathrm{CH}$ and $\mathrm{C}-\mathrm{S}-\mathrm{H}$ in terms of kinetics, microstructure changes and moisture properties. Cem Concr Res 56:153-170

[42] Glasser F, Matschei T (2007) Interactions between Portland cement and carbon dioxide. ICCC, Montreal

[43] Myneni SCB, Traina S, Waychunas GA, Logan TJ (1998) Vibrational spectroscopy of functional group chemistry and arsenate coordination in ettringite. Geoch Cosmoch Acta 62:349-3514

[44] Matschei T, Lothenbach B, Glasser FP (2007) The AFm phase in Portland cement. Cem Concr Res 37:118-130

[45] Castellote M, Fernandez L, Andrade C, Alonso C (2009) Chemical changes and phase analysis of OPC pastes carbonated at different $\mathrm{CH}$ concentrations. Mater Struct 42:515-525

[46] Johannesson B, Utgenannt P (2001) Microstructural changes caused by carbonation of cement mortar. Cem Concr Res 31:925-931

[47] Silva AC, Savastano H Jr, John VM (2009) Envelhecimento de compósitos à base de escória de alto-forno reforçados com polpa celulósica residual de eucalipto. Ambient Constr $9(1): 25-44$
[48] Hyvert N, Sellier A, Duprat F, Rougeau P, Francisco P (2010) Dependency of $\mathrm{C}-\mathrm{S}-\mathrm{H}$ carbonation rate on $\mathrm{CO}_{2}$ pressure to explain transition from accelerated tests to natural carbonation. Cem Concr Res 40:1582-1589

[49] Pu Q, Jiang L, Xu J, Chu H, Xu Y, Zhang Y (2012) Evolution of $\mathrm{pH}$ and chemical composition of pore solution in carbonated concrete. Constr Build Mater 28:519-524

[50] Almeida AEFS, Tonoli GHD, Santos SF, Savastano H Jr (2010) Carbonatação acelerada efetuada nas primeiras idades em compósitos cimentícios reforçados com polpas celulósicas. Ambient Const 10(4):233-246

[51] Almeida AEFS, Tonoli GHD, Santos SF, Savastano H Jr (2013) Improved durability of vegetable fiber reinforced cement composite subject to accelerated carbonation at early age. Cem Concr Compos 22:49-58

[52] Fernández-Bertos M, Simons SJR, Hills CD, Carey PJ (2004) A review of accelerated carbonation technology in the treatment of cement-based materials and sequestration of $\mathrm{CO}_{2}$. J Hazard Mater B112:193-205

[53] Rostami V, Shao Y, Boyd AJ (2011) Durability of concrete pipes subjected to combined steam and carbonation curing. Constr Build Mater 25(8):3345-3355

[54] Thiery M, Villain G, Dangla P, Platret G (2007) Investigation of the carbonation front shape on cementitious materials: effects of the chemical kinetics. Cem Concr Res 37:1047-1058

[55] Coussy O, Dangla P, Lassabatere T, Baroghel-Bouny V (2004) The equivalent pore pressure and the swelling and shrinkage of cement-based materials. Mater Struct Concr Sci Eng 37:15-20

[56] Odler I, Colán-Subauste J (1999) Investigations on cement expansion associated with ettringite formation. Cem Concr Res 29:731-735

[57] Pavoine A, Brunetaud X, Divet L (2012) The impact of cement parameters on delayed ettringite formation. Cem Concr Compos 34:521-528 